\title{
EFEKTIFITAS E-LEARNING DI KALA PANDEMI PADA PELAJAR SMA (STUDI KASUS PELAJAR SMAN 1 KRIAN)
}

\author{
Arvian Messianik Putra As Shamad \\ Program studi Sosiologi, Fakultas FISH, Universitas Negeri Surabaya \\ arvian.19040@mhs.unesa.ac.id
}

\begin{abstract}
ABSTRAK
Pandemi covid-19 yang terjadi di Indonesia membuat perubahan pada dunia pendidikan, pendidikan yang awalnya berbasis tatap muka dirubah menjadi berbasis e-learning, penelitian ini dilakukan guna mengetahui efektifitas e-learning di kala pandemi pada pelajar SMA di SMAN 1 Krian. Penelitian ini bersifat kualitatif. Teknik pengumpulan data berupa observasi dan wawancara. Subjek penelitian merupakan pelajar dari SMAN 1 Krian. Teknik analisis berupa mengembangkan dan menafsirkan data yang diperoleh dari peristiwa peristiwa serta kejadian yang terjadi. Hasil penelitian menunjukan efektifitas pembelajaran berbasis e-learning di kala pandemi masih kurang efektif. Hal ini disebab kan oleh pertama model pembelajaran yang tidak efektif, kontrol kepada peserta didik yang kurang, gadget yang tidak memadai, koneksi internet yang buruk, sistem e-learning buatan sekolah yang sering down
\end{abstract}

Kata kunci: Pandemi Covid-19, Pendidikan, E-Learning.

\section{ABSTRACT}

The covid-19 pandemic that occurred in Indonesia made changes to the world of education, education which was originally based on face-to-face was changed to based on e-learning, this research was conducted to determine the effectiveness of e-learning during a pandemic in high school students at SMAN 1 Krian. This research is qualitative in nature. Data collection techniques in the form of observation and interviews. The research subjects were students from SMAN 1 Krian. The analysis technique is in the form of developing and interpreting data obtained from events and events that occur. The results showed that the effectiveness of e-learning based learning during the pandemic was still ineffective. This is caused by the first ineffective learning models, inadequate control of students, inadequate gadgets, bad internet connection, school-made e-learning systems that are often down.

Keywords: Covid-19 Pandemic, Education, E-Learning.

\section{PENDAHULUAN}

Pandemi Covid-19 yang terjadi di seluruh dunia memaksa perubahan perilaku dalam seluruh aspek kehidupan manusia, termasuk Indonesia. Perubahan perilaku tersebut juga berdampak kepada perubahan metode belajar-mmengajar. Kondisi pandemi yang memaksa untuk mengurangi sosialisasi secara langsung mengakibatkan kegiatan belajar mengajar, hal ini berdampak dilakukan pembelajaran e-learning kepada seluruh jenjang pendidian termasuk SMA (Hidayat et al., 2020). Tenaga pendidik dan murid mau tak mau harus melakukan pembelajaran secara online atau tidak dilaksanakan secara tatap muka di kelas seperti biasanya. Kejadian pandemi covid-19 ini memaksa guru dan siswa untuk belajar dan beradaptasi dengan keadaan dengan melakukan pembelajran jarak jauh. Pembelajaran harus tetap dilaksanakan disaat pandemi covid-19 agar generasi penerus tidak tertinggal pembelajaran dan terus bisa menjadi generasi penerus yang gemilang demi kemajuan generasi penerus di masa mendatang (Priyanto \& Ag, 2020).

Pola pembelajaran yang konvesional seperti pembelajaran tatap muka dikala pandemi seperti ini digantikan oleh pembelajaran jarak jauh menggunakan metode e- 
learning tanpa menggunakan metode tatap muka sama sekali dan digantikan dengan metode tanpa tatap muka serta diskusi secara online dengan memanfaatkan teknologi yang ada dan segala platform yang tersedia. Pendidikan jarak jauh adalah pendidikan yang peserta didiknya berada terpisah dari pendidiknya dan media pembelajarannya menggunakan berbagai sumber melalui teknologi komunikasi, informasi, dan media yang lainnya (Nasional, 2003).

Pada saat kondisi pembelajaran jarak jauh atau e-learning seperti ini guru dan murid tidak bisa dilepaskan dari alat komunikasi seperti penggunnaan gadget dan diperlukan kkoneksi internet yang memadai yang dapat dimanfaatkan untuk e-learning. Pemanfaatan berbagai platform juga dapat menunjang proses pembelajaran e-learning sehingga kegiatan belajar mengajar dapat dilaksanakan secara lancar. Kegiatan pembelajaran menggunakan metode e-learning mengharuskan guru untuk membekali peserta didiknya dengan pendidikan dan keterampilan untuk berpikir kritis, konstruktif, inovativ dan berkarakter seehingga diharapkan peserta didik dapat menjadi ujung tombak perubahan pada masa yang mendatang (Gusty et al., 2020).

Abad 21 seharusnya menjadi panggung bagi pendidikan jarak jauh, karena dalam sistem pendidikan metode pembelajaran jarak jauh menjadi sistem paling efektif (Lenar et al., 2014) ditambah lagi di kala pandemi seperti ini pembelajaran jarak jauh menjadi hal yang paling populer dilakukan dalam kegiatan belajar mengajar. Namun dalam pelaksanaanya ditemukan banyak sekali kendala maupun keefektifan PJJ, banyak yang berfikir PJJ akan lebih memudahkan proses belajar mengajar ketimbang proses belajar konvensional. Saat ini pembelajaran e-learning di Indonesia memiliki banyak kendala seperti tidak semua siswa memiliki gadget yang memadai, terbatasnya akses internet, keterbatasan teknologi, dan kurangnya keterampilan dan kualitas pengajar.

Media internet pada e-learning memiliki kendala yang cukup besar seperti koneksi internet yang tidak merata, server eror atau pun kesalahan teknis, hal ini dapat menghambat pembelajaran berbabis e-learning (Nurmukhametov et al., 2015). Pembelajaran e-learning membutuhkan kreatifitas dari pengajar untuk memberikan materi karena dapat menaikkan minat belajar siswa, karena setiap siswa memiliki permasalahan sendiri dalam menerima materi (Simbolon, 2014).

Dari pendahuluan diatas maka perumusan masakah dari artikel ini adalah: pertama, bagaimana efektifitas e-learning di kala pandemi pada pelajar studi kasus pelajar SMAN 1 Krian? Kedua, apa saja kendala siswa dalam melaksanakan e-learning di masa pandemi seperti saat ini? Sementara tujuan dibuatnya artikel ini adalah mengetahui efektifitas elearning pada pelajar di SMAN 1 Krian.

\section{METODE PENELITIAN}

Metode yang digunakan adalah metode penelitian kualitatif yang memperoleh data dengan cara melakukan observasi wawancara, metode ini mengembangkan dan menafsirkan data yang diperoleh dari peristiwa peristiwa serta kejadian yang terjadi, sementara pendekatan yang akan digunakan adalah pendekatan studi kasus. Subjek yang akan diteliti adalah 5 (lima) orang pelajar dari SMAN 1 Krian. Teknik pengumpulan data yang akan dilakukan dengan cara observasi dan wawancara. 


\section{HASIL PENELITIAN DAN PEMBAHASAN}

\section{Pembelajaran E-Learning di Masa Pandemi}

Pandemi Covid-19 yang menyebar di Indonesia membuat pemerintah menetapkan kebijakan meliburkan siswa dari pendidikan konvesional tatap muka dan merubahnya menjadi pendidikan daring atau online, hal ini di tetapkan pemerintah melalui kebijakan Menteri Pendidikan dan Kebudayaan Republik Indonesia terkait Surat Edaran Nomor 4 Tahun 2020 tentang Pelaksanaan Kebijakan Pendidikan dalam Masa Darurat Penyebaran Corona Virus Disease (COVID-19).

Meskipun pandemi covid-19 masih terjadi namun pendidikan harus tetap berjalan dan harus dilakukan pembelajaran. Pembelajaran sendiri adalah sebuah komunikasi dan interaksi dua arah. guru sebagai pendidik memiliki tugas untuk mengajar, sedangkan murid sebegai peserta didik memili tugas untuk belajar. Pembelajaran dilakukan oleh guru sebagai proses untuk mengembangkan kreativitas dan potensi dari peserta didik, sehingga diharapkan dapat meningkatkan kemampuan peserta didik serta dapat mengkontruksi pengetahuan baru sehingga peserta didik memiliki kemampuan pengusaan terhadap materi pembelajaran (Lubis et al., 2018).

Covid-19 yang berdampak kepadana dunia pendidikakan mengharuskan perubahan pada bentuk pendidikan, hal ini mengakibatkan berbagai elemen terkait harus bekerja sama untuk mewujudkan pendidikan yang efektif dikala pandemi seperti ini. Meskipun begitu pendidikan yang efektif dikala pandemi seperti ini belum dapat dikatakan sempurna, masih banyak sekali hal yang kurang di sistem pendidikan dikala pandemi seperti ini. Namun begitu kerja keras dari pemangku tanggung jawab harus diacungi jempol karena alternatif pendidikan yang di wujudkan masih dapat digunakan dikala darurat seperti ini, lebih baik ketimbang tidak ada sama sekali.

Sistem pendidikan berbasis maya atau biasa disebut e-learning merupakan sistem pendidikan yang tidak terbatas ruang dan waktu yang telah menggantikan peran dari pendidikan konvesional berbasis tatap muka dikarenakan pandemi covid-19 (Irawan et al., 2020). Pendidikan berbasis maya merupakan salah satu alternatif dari pendidikan di masa pandemi agar kegiatan belajar mengajar tetap bisa berjalan. Sistem pendidikan berbasis elearning memiliki dua sisi yang berlawanan, disisi lain sistem ini membantu untuk kegiatan belajar mengajar tetap berjalan meskipun di saat pandemi sekalipun dan bisa dilaksanakan hingga pandemi ini berakhir. Tetapi disisi yang lain sistem ini memunculan masalah baru, yakni terjadinya pembelajaran yang kurang efektif ketimbang pembelajaran konvesional dikelas. kondisi ini dikeluhka oleh peserta didik yang merasa tidak bisa belajar secara maksimal seperti pendidikan berbasis tatap muka.

Pendidikan berbasis e-learning mengharuskan tenaga pendidik untuk berpikir lebi kreatif dan dituntut untuk mampu melaksanakan pembelajarann daring melalui berbagai platform media seperti video dan slide presentasi. Tenaga pendidik juga dituntut untuk menguasai perangkat dan media daring sehingga dapat memberikan materi ajar yang tepat dan efektif. Hal ini bisa dikatakan sebagai hal positif dikarenakan pembelajaran daring berarti memberikan kesempatan yang lebih luas untuk materi dan tenaga pendidik dapat mengeksplorasi materi yang dapat diberikan, namun dalam kenyataan dilapangan banyak dari tenaga pendidik yang dirasa masih gagap teknologi sehingga pembelajaran yang dirasakan peseta didik kurang efektif.

Dalam pendidikan berbasis e-learning diperlukan sarana dan prasarana penunjang yang tidak kalah penting ketimbang pendidikan konvesional berbasis tatap muka, jika 
pendidikan konvesional berbasis tatap muka diperlukan sarana dan prasaran seperti ruang kelas yang memadai dan media pembelajaran yang interaktif dan mengikuti jaman, pada pendidikan berbasis e-learning juga diperlukan sarana dan prasarana penunjang agar pebelajaran tetap berjalan secara maksimal dan sesuai dengan tujuan pendidikan yang diharapkan sehingga pendidikan di masa seperti ini tetap bisa berjalan tanpa kendala. Pada pendidikan berbasis e-learning diperlukan perhatian lebih dari pihak pengajar, sekolah, ataupun dari pihak pemerintah (Darmayanti et al., 2007).

\section{Perbedaan Pembelajaran Tatap Muka Dengan Pembelajaran Berbasis E-Learning}

Pandemi virus covid-19 yang melanda Indonesia membuat pendidikan di negeri ini menjadi berubah 180 derajat, pendidikan yang sebelumnya berbasis tatap muka di ubah menjadi pendidikan berbasis e-learning, hal ini disebabkan untuk mencegah agar virus covid-19 tidak semakinn menyebar dan tidak menginfeksi peserta didik yang merupakan generasi penerus bangsa. Pada pendidikan berbasis e-learning ini guru sebagai pendidik harus bisa memastikan peserta didik tetap bisa mengikuti pembelajaran meskipun harus dirumahkan.

Sarana dan prasarana yang diperlukan pada pembelajaran berbasis e-learning sebenarnya tidak sekomplek pada pembelajaran konvesional berbasis tatap muka, pada sistem pembelajaran berbasis e-learning sebernarnya hanya diperlukan gadget yang memadai dan koneksi internet yang dapat mendukung aktivitas pembelajaran. Sehingga pada pembelajaran berbasis e-learning aktivitas pembelajaran dapat dilakukan dimana saja dan kapan saja. Namun hal ini juga bukan tanpa masalah, masalah baru sekarang muncul yakni tiidak semua peserta didik memiliki sarana dan prasarana yang dapat menunjang aktivitas pembelajaran, terutama pada masalah kuota internet yang banyak dikeluhkan oleh peserta didik (Yustanti, 2021).

Interaksi antar peserta didik di sistem pendidikan berbasis e-learning seperti saat ini juga dirasa kurang oleh peserta didik, mereka merasa tidak dapat bersosialisasi antar teman sehingga membuat peserta didik malas. Pada pembelajaran berbasis e-learning juga peserta didik mengeluhkan pemberian materi yang tidak dapat dilaksanakan dengan baik dan juga sulit untuk memahami pembelajaran (Hawari, 2020). Peserta didik juga mengeluhkan tidak bisa menghabiskan masa SMA yang merupakan sebuah masa yang pengalamannya begitu penting.

\section{Dukungan Pihak Sekolah Terhadap Sistem Pembelajaran E-Learning}

Pihak sekolah tentunya tidak bisa lepas tangan begitu saja terhadap pembelajaran elearning, pihak sekolah harus bertanggung jawab atas ke efektifitasan dan kesuksesan pembelajaran berbasis e-learning. Keefektififan pembelajaran tergantung dari bagaimana pihak pengajar dan pihak sekolah bagaimana dalam mengola sistem pengajaran, pengajar harus bisa berinovasi agar pembelajaran bisa berjalan secara efektif. Sistem pembelajaran yang tidak bisa melalui tatap muka menjadi sebuah tantangan karena tidak bisa memberi materi secara langsung. Sistem pembelajaran berbasis e-learning melalui gadget seperti hp dan laptop menjadi sebuah tantangan baru. Pihak pengajar harus membuat peserta didik tetap memiliki semangat untuk mengikuti pembelajaran, karena disaat pembelajaran berbasis e-learning seperti ini pengajar tidak bisa mengontrol peserta didik secara langsung (Yuliani et al., 2020).

Bantuan kuota dari pihak sekolah ataupun pemerintah juga menjadi dukungan yang penting dikala pembelajaran berbasis e-learning seperti ini, kuota yang bisa dikategorikan mahal untuk kebanyakan peserta didik menjadi barang mewah saat ini, pembelajaran 
berbasis e-learning membutuhkan kuota yang tidak sedikit sehingga bantuan kuota dari pihak sekolah ataupun pemerintah setiap bulan menjadi hal yang paling ditunggu oleh peserta didik (Mastuti et al., 2020).

\section{Dukungan Pihak Orang Tua Terhadap Sistem Pembelajaran E-Learning}

Peserta didik yang dirumahkan tentu saja menyebabkan orang tua memiliki peran yang besar agar pembelajaran tetap berjalan sesuai yang di harapkan. Peserta didik yang sebelumnnya pendidikannya dilimpahkan ke guru sekarang orangtua juga memiliki andil dalam pendidikan anaknya. Pembelajaran e-learning memiliki pekerjaan rumah bagaimana mengontrol peserta didik agar dapat mengikuti atau memahami materi seperti pada pembelajaran konvesional, pada seperti ini peran orang tua dibutuhkan untuk mengkontrol anaknya sehingga pembelajaran lebih efektif (Nurofik et al., n.d.).

\section{PENUTUP}

Pandemi covid-19 menghasilkan banyak pekerjaan rumah bagi pendidikan di Indonesia, pembelajaran e-learning yang diterapkan ternyata belum bisa menghasilkan pendidikan yang efektif dan dapat menunjang keberhasilan pendidikan. Masih banyak pekerjaan rumah bagi pemerintah, pengajar, orangtua, dan pelajar itu sendiri. Pengajar yang harus memikirkan bagaimana mengkontrol peserta didiknya dan metode pembelajaran apa yang tepat sehingga dapat memberikan pendidikan yang efektif. Orang tua yang harus lebih pro aktif untuk mendukung pembelajaran anaknya, dan siswa yang tetap harus semangat meskipun pembelajaran yang dilakukan melalui e-learning

Terdapat beberapa faktor yang menyebabkan pendidikan berbasis e-learning belum efektif, pertama model pembelajaran yang tidak efektif, kontrol kepada peserta didik yang kurang, gadget yang tidak memadai, koneksi internet yang buruk, sistem e-learning buatan sekolah yang sering down. Masih banyak terdapat pekerjaan rumah yang harus diselesaikan, kedepannya semoga pandemi ini cepat berlalu dan pembelajaran berbasis tatap muka dapat di jalankan.

\section{DAFTAR PUSTAKA}

Darmayanti, T., Setiani, M. Y., \& Oetojo, B. (2007). E-learning pada pendidikan jarak jauh: konsep yang mengubah metode pembelajaran di perguruan tinggi di Indonesia. Jurnal Pendidikan Terbuka Dan Jarak Jauh, 8(2), 99-113.

Gusty, S., Nurmiati, N., Muliana, M., Sulaiman, O. K., Ginantra, N. L. W. S. R., Manuhutu, M. A., Sudarso, A., Leuwol, N. V., Apriza, A., \& Sahabuddin, A. A. (2020). Belajar Mandiri: Pembelajaran Daring di Tengah Pandemi Covid-19. Yayasan Kita Menulis.

Hawari, A. (2020). E-Learning Berbasis Virtual classroom di Era Covid-19: Iwan Hermawan. Hawari: Jurnal Pendidikan Agama Dan Keagamaan Islam, 1(1).

Hidayat, M. T., Hasim, W., \& Hamzah, A. (2020). Pembelajaran Daring Selama Pandemi Covid-19: Solusi atau Masalah Baru dalam Pembelajaran? Journal Civics \& Social Studies, 4(2), 47-56.

Irawan, E., Arif, S., Hakim, A. R., Fatmahanik, U., Fadly, W., Hadi, S., Pertiwi, F. N., Fauziah, H. N., Santoso, L., \& Pahlevi, F. S. (2020). Pendidikan Tinggi Di Masa Pandemi: Transformasi, Adaptasi, dan Metamorfosis Menyongsong New Normal. Zahir Publishing. 
Jumal Sosialisasi

Jurnal Hasil Pemikiran, Penelitian, dan Pengembangan Keilmuan Sosiologi Pendidiikan

Vol 8, Nomor 1, Maret 2021

Lenar, S., Artur, F., Ullubi, S., \& Nailya, B. (2014). Problems and decision in the field of distance education. Procedia-Social and Behavioral Sciences, 131, 111-117.

Lubis, W., Sagala, S., Saragih, A. H., \& Sagala, G. H. (2018). The Potentiality of Principal Leadership Implementation In North Sumatera. 3rd Annual International Seminar on Transformative Education and Educational Leadership (AISTEEL 2018), 693-698.

Mastuti, R., Maulana, S., Iqbal, M., Faried, A. I., Arpan, A., Hasibuan, A. F. H., Wirapraja, A., Saputra, D. H., Sugianto, S., \& Jamaludin, J. (2020). Teaching from home: Dari belajar merdeka menuju merdeka belajar. Yayasan Kita Menulis.

Nasional, D. P. (2003). Undang-Undang Nomor 20 Tahun 2003 Tentang Sistem Pendidikan Nasional. Jakarta: Depdiknas, 33.

Nurmukhametov, N., Temirova, A., \& Bekzhanova, T. (2015). The problems of development of distance education in Kazakhstan. Procedia-Social and Behavioral Sciences, 182, 15-19.

Nurofik, A., Al'asqolaini, M. Z., \& Noviyanti, L. O. S. (n.d.). PROSES KEGIATAN BELAJAR MENGAJAR (KBM) PADA MASA PANDEMI COVID-19 DI PERGURUAN TINGGI INDONESIA.

Priyanto, A., \& Ag, M. (2020). PEMBELAJARAN DARING. Penerapan Adaptasi Kebiasaan Baru Pada Era Pandemi Virus Corona 19 Di Berbagai Sektor Pendidikan, 41.

Simbolon, N. (2014). Faktor-faktor yang mempengaruhi minat belajar peserta didik. Elementary School Journal Pgsd Fip Unimed, 1(2).

Yuliani, M., Simarmata, J., Susanti, S. S., Mahawati, E., Sudra, R. I., Dwiyanto, H., Irawan, E., Ardiana, D. P. Y., Muttaqin, M., \& Yuniwati, I. (2020). Pembelajaran Daring untuk Pendidikan: Teori dan Penerapan. Yayasan Kita Menulis.

Yustanti, N. M. S. D. (2021). ANALISIS KESIAPAN GURU KIMIA DAN SISWA KELAS X DAN XI MIPA SMA NEGERI 4 SINGARAJA DALAM PEMBELAJARAN BERBASIS E-LEARNING. Universitas Pendidikan Ganesha. 